\title{
Psycho-Pedagogical Approaches to the Design of English Learning Course for Ship Engineers
}

\author{
https://doi.org/10.3991/ijep.v10i6.14107 \\ O.Tyron $\left.{ }^{(}\right)$, S. Korieshkova, M. Didenko, S. Kaminska \\ State University of Infrastructure and Technologies, Kyiv, Ukraine \\ tyronolena@gmail.com
}

\begin{abstract}
Ship engineers are civil engineers with special knowledge of marine and water transport engineering therefore the article appeals to the lecturers of English for engineering students. The authors of this article share the experience of experimental English language training which was preceded by a thorough study of the theoretical works of contemporary scholars and practitioners in the field of foreign language training of civil and marine engineers. Summarizing new trends led to defining a complex of approaches which makes the design of the course efficient. The results of the experimental training allowed to formulate practical recommendations how to realize new trends and approaches in the textbooks' design, taking into account qualitative changes both in the field of educational technologies and in the cognitive abilities of students. We proved that the complex of offered approaches provide better education and reflect the changes in psychology, philosophy, and pedagogy along with new technological platforms. We offer additional discussions concerning creating a modular course of English for ship engineers which could be internationally accepted by institutions that train specialists for the marine industry. The marine industry is globalized therefore, uniform standards for the training of seafarers are important and the idea to have the module course of English for ship engineers would be enthusiastically welcomed by all countries.
\end{abstract}

Keywords - English for ship engineers, development of professional and linguistic competencies, use of digital technologies, the language of science and technologies, learner-centered approach

\section{Introduction}

The receipt and processing of scientific information from local and international sources is an integral characteristic of a modern engineer. Higher education institutions that train engineers for the marine industry primarily train engineers and should reflect the modern trends of civil engineers' foreign language training. Based on this, we emphasize that while training future ship engineers it is necessary to teach not only the specific technical English of mariners but also the language of science and technology. Ship engineers are civil engineers with special knowledge of marine and water transport engineering. English language competency of ship engineers should comply with the 
requirements of the International Maritime Organization (IMO). Under the International Convention on Standards of Training, Certification and Watchkeeping for Seafarers (STCW) [11], all officers in charge of a watch (navigational or engineering) must have a good command of spoken and written English. Developing countries may be assisted with Model Course 3.17 developed by the International Shipping Federation of London in 2000 [7]. In order to assist the instructors of Maritime English, references of the Model Course indicate key textbooks, maritime publications, additional technical material, video material and other teaching aids which the instructor may use while preparing instructional programmes. We do not criticize the existing Model Course, but we feel the need to update it because 20 years is the period during which a new generation of sailors has grown, so we must take into account qualitative changes both in the field of marine industry technologies and in the cognitive abilities of students. Therefore, we contend that the modern instructional plans for teaching ship engineers must reflect these changes.

The main aim of our article is to show the new approach to organizing teaching material for the process of English language acquisition by ship engineers. The novelty of the approach consists in combining modern views on the programmes for teaching a foreign language to future engineers in terms of pedagogy, methodology and psychology. The analysis of the theoretical scientific literature allowed to highlight certain obsoleteness of existing instructional materials and to determine the current requirements of society for the training of engineers. By sharing our experience of organizing teaching English for ship engineers at State University of Infrastructure and technologies of the Kyiv Institute of Water Transport (Ukraine) prove that it became urgent 1) to introduce changes into instructional plans taking into account cognitive abilities of students; 2) create textbooks based on anthropological peculiarities of local language; 3) combine basic, professional and linguistic competencies creating textbooks for learning English for future engineers.

The object of our research is the teaching English for ship engineers, the subject is the content of the students' books of English.

The tasks of the research are: 1) to develop Engineering Pedagogy by adding an effective approach for teaching English for future engineers; 2) to design a 4-year course of English for ship engineers (Bachelor degree); 3) to prove the efficiency of students' books through experimental training; 4) to develop recommendations to the teachers of English for civil engineers how to organize instructional material.

\subsection{Research methods}

1. Theoretical: Analysis and systematization of scientific-theoretical and methodological sources, analysis and generalization of experimental data

2. Empirical: Conversation, survey, testing

3. Experimental training: Technologies of psycho-pedagogical support for the formation of foreign language competence of the future ship engineer to optimize the process of learning English

4. Mathematical and statistical methods of empirical data processing: Attendance dynamics analysis, ranking and descriptive analysis, unpaired t- test. 


\section{Description of the Experimental Course of English for Ship Engineers}

\subsection{Theories used}

We reviewed the scientific publications on the issues which prove the necessity to create updated instructional programmes and materials for the foreign language training of ship engineers. A review of the scientific literature on current trends in the training of future engineers has identified five ideas that indicate the need for changes in approaches to the formation of foreign language competence of future engineers. We have developed these ideas into approaches to the organization of educational material because it is a solid scientific base that makes educational materials successful.

The first idea is that updated instructional programmes and materials should reflect basic competency and anthropology approach.

The European Union has suggested eight key competencies. The competencies which can be realized through English for engineers are communication in a foreign language; basic competences in science and technology; digital competence; learning to learn; social and civic competences; the sense of initiative; cultural awareness.

The anthropology of learning and cognition asks questions about how culture and psyche make each other and, through research in cultural aspects of learning and cognition, tries to probe deeper into the problems on how culture and learning influence behavior and mental processes [4]. In this respect, developing the 4-year program of teaching English, we took into account the peculiarities of national phonetics and grammar and its impact on the student's reproductive linguistic capabilities. We sustain the traditions of Ukrainian communication but emphasize the cultural diversity from the first year of study and educate tolerance to this diversity.

The second idea is that updated instructional programmes and materials should reflect the combination of professional and linguistic competency.

In recent times, a trend has emerged whereby teachers integrate the acquisition of content on the one hand and development of language competence on the other [12, p.311]. Some scientists [16] say that future marine engineers are required to transfer their knowledge and skills from their learning environments to their work situation. The authors emphasize that changes in technology must be taken into account while working out instructional programmes for teaching specialists in the engineering sphere.

In order to realize this idea, we used simulators of some technical systems (not complicated), watched videos about engineers' activity in the engine room aboard the ships, had classes in the laboratories, studied cases from the Internet resources, presented role games. Of course, the learning environment is important, but we accentuate that we teach language therefore we caution against substituting language training with teaching a specialty in English.

The linguistic component of the process of training a future ship engineer includes the following competencies: dialogical and monologic speaking, listening, reading and writing. 
The third idea is that updated instructional programmes and materials should include e-learning techniques. E-learning describes a set of technology-mediated methods that can be applied to support student learning and can include elements of assessment, tutoring, and instruction [22]. Teachers are worried about the decline of interest in their teaching, and therefore they are trying to make their lessons more interesting. Therefore, they consider different digital means and interactive educational activities as effective resources of making learning more attractive [24].

The instructional design of Maritime English must satisfy what learners and crewing companies might be expecting. Developing textbooks for the entire undergraduate course, our task was to include materials for electronic training in textbooks. We included Q- code, according to which students could immediately establish contact through a smartphone via a link. Such a combination of a textbook and e-learning material is realized as blended learning which combines face-to-face with technologybased learning and instruction. The terms "blended learning" and "hybrid learning" are used interchangeably in instructional science. However, a blended learning scenario is also regarded as a combination of different computer-based technologies, a combination of different pedagogical approaches and theories, or a combination of instructional technology with specific tasks in order to facilitate desired skills and competencies [6].

The fourth idea is that updated instructional programmes and materials should reflect the language of science and technology. Science and technology are becoming very important sections within the areas of humanism and educational technology. B. Schmidt (2015) stresses that "it is important to find papers which align closely not only to theoretical course content but to other course work as well. Much care should be taken to establish a very clear framework for how the students are expected to work with an authentic paper to avoid frustration and a negative learning experience" [20]. According to D. Martin [13] digitalization is the process that turns activities, information and results into data that can be compiled, analyzed and shared. Data has become the economy's most important asset and its volume is constantly increasing. Some analysts say that the volume of digital data available worldwide is set to grow tenfold between 2013 and 2020. "Rapidly changing technology has always created a gap between the static model of competency standards set by MET institutions and the dynamic nature of the competence model demanded by the changing technology. There is a perpetual time lag in bridging this gap and as a rapid and short -term measure; there are increasingly high demands for proactive training measures e.g. training in the electronic controls on intelligent engines. This inevitable gap varies amongst MET institutions on national as well as on international scale [16, p. 2311]. We found a vivid example of rapid changes in technology closely connected with the question of using elearning. While the teachers and scientists are discussing the advantages and disadvantages of it, Álvaro Hernán Galvis [4] describes the evolution of educational models, materials and support technologies. The author describes the e-learning of three generations. The first generation-model centered on materials. Materials and technologies used are audio conferencing, videoconferencing, instructional software, e-books and paper format content. The second generation-model centered on the virtual classroom. Materials and technologies used are video streaming, online material, access to the Internet resources, beginning of interaction in the form of e-mails and forums. The third- 
generation model centered on flexibility and participation. Materials and technologies used are specialized content generated by specialists and also by students, reflections in the form of blogs, interactive technologies in the form of games, simulators, online visualization, online learning communities and smartphone learning.

Now we can talk about a new generation of students who grew up with modern technology. They do not need to learn how to use it; they do not wait for directions where to find the translation of the word and how to find the necessary information. The teacher needs to adapt to the student's cognition abilities and recognize that some teaching methods are already outdated.

The fifth idea is that updated instructional programmes and materials should reflect a learner-centered approach. The teacher is pushing the learning material to students step by step. In such teacher-centered learning activity, the learners play a passive role expecting to be provided with new knowledge that they can add to their existing background. The learners are thinking and making connections with their ideas and experiences and get actively involved. However, if the learner is not able to make necessary cognitive connections due to limited knowledge and experience, if the new information is too complicated, if it is delivered too quickly, the learner may not be able to keep himself/herself actively involved. This type of passive learning may lead to learners' cognitive dissociation with the discourse. Such students will fail to master the material and then will need to make new efforts for learning through self-reading or peer help. Teacher-centered pedagogies that lack commitment or interaction often lead students to adopt a passive attitude to learning while encountering focus problems and not taking responsibility for their own learning [21].

We introduced new ideas on how to organize English language acquisition by ship engineers. To introduce new ideas not always easy because we must prove that they provide a better education given the aims setting the course and their applicability with regard to shaping educational content. [9]. New theoretical frameworks in psychology, philosophy, and pedagogy along with new technological platforms for aiding the delivery of instruction and the analysis of learning are shifting thinking for framing learning goals and designing science learning environments. The scientist stresses the shift of learning goals [2].

\subsection{Defining criteria}

We determined three criteria for the efficiency estimation of the experimental course of English for ship engineers: 1) the decisions of a representative of a crewing company to reject the applicant (the student applying for the position of Engine Cadet); 2) the results of international tests for Engine Cadets; 3) attendance dynamics.

The most important and primary for us was the decisions of the representatives of crewing companies. Such a choice is justified since the main goal of the educational institution is to prepare a competitive specialist for maritime industry. The student's opportunity to get the start of his career largely depends on the success of the interview in the crewing company. The role of crewing companies is proved by many scientists and they give clear evidence why. The mixing of seafarers of different nationalities to compose shipping crew requires specialized knowledge in order to ensure that these 
mixed crews will be both low-cost and effective [14]. The authors state that the existence of separate markets for seafarers makes it possible to distinguish between groups in the seafaring labour force and to give them differing incomes. Under these circumstances, subcontracting to specialist firms became quite an attractive choice. As ship management firms have developed and expanded, they became the world's largest employers of seafarers [17].

\subsection{Defining content}

As you see in table 1, future ship engineers should exhibit adequate knowledge of the English language to enable the officer to use engineering publications and to perform the officer's duties. Therefore, the professional discourse of a ship engineer can be roughly divided into such main spheres:

- Communication for professional purposes

- Getting information from technical publication

Table 1. Standards regarding the Engine Department (taken from STCW)

\begin{tabular}{|l|l|l|l|}
\hline \multicolumn{1}{|c|}{ Competence } & $\begin{array}{l}\text { Knowledge, understanding } \\
\text { and proficiency }\end{array}$ & $\begin{array}{c}\text { Methods for } \\
\text { demonstrating } \\
\text { competence }\end{array}$ & $\begin{array}{r}\text { Criteria for evaluating } \\
\text { competence }\end{array}$ \\
\hline $\begin{array}{l}\text { Use English in } \\
\text { written and oral } \\
\text { form }\end{array}$ & $\begin{array}{l}\text { Adequate knowledge of the } \\
\text { English language to enable } \\
\text { the officer to use engineering } \\
\text { publications and to perform } \\
\text { the officer's duties }\end{array}$ & $\begin{array}{l}\text { Examination and as- } \\
\text { sessment of evidence } \\
\text { obtained from practi- } \\
\text { cal instructions }\end{array}$ & $\begin{array}{l}\text { English language publications rel- } \\
\text { evant to the officer's duties are } \\
\text { correctly interpreted Communica- } \\
\text { tions are clear and understood }\end{array}$ \\
\hline
\end{tabular}

Further investigation of STCW Convention requirements to Marine engineering at the operational level we see the items closely connected with English language reading, writing and speaking skills, such as:

5. Maintenance of the machinery space logs and the significance of the readings taken a proper record is maintained of the movements and activities relating to the ship's engineering systems

6. Operate fuel, lubrication, ballast and other pumping systems and associated control systems operations are planned and carried out in accordance with operating manuals

7. Prevention of pollution of the marine environment ensuring compliance with MARPOL (Marine Pollution) requirements

8. Knowledge and ability to apply decision-making techniques

9. Marine engineering at the management level. Manage the operation of machinery performance levels are in accordance with technical specifications.

This information, taken from STCW helped us to form the English for professional communication. 
Skills we develop: 1) describing types of technical problems; 2) describing the causes of faults; 3) discussing repairs and maintenance; 4) describing safety precautions; 5) discussing regulations and standards; 6) simplifying technical specifications; 7) describing the construction of main and auxiliary machinery; 8) analyzing advantages and disadvantages of systems; 9) describing technical functions; 10) discussing quality, etc.

The other challenge was to select the discourse to train the students to get information from technical publications. We defined it as the English of science, engineering and innovations.

Skills we develop: 1) working with drawings; 2) resolving design problems; 3) explaining how technology works; 4) describing improvements and design; 5) explaining views, theories and predictions; 6) explaining tests and experiments; 7) simplifying illustrations (texts) of technical innovations; 8) making own project presentations, etc.

\subsection{Practical recommendations on the organization of educational course of English for ship engineers}

Experimental training has been running since 2016 and is designed for 4 years of study. The Bachelor Curriculum includes 4 years of Foreign Language and is divided into the following subjects:1 year General English; 2nd and 3rd year English for Professional Purposes; 4th year Business English. We have prepared textbooks for testing in all foreign language courses.

In table 2 we show how we reflected the main 5 approaches in the design of instructional programmes, textbooks and instructional materials. We would like to describe the psychological and pedagogical approaches to conducting experimental training, without going into listing the names of topics and texts.

The implementation of psychological and pedagogical approaches made it possible to formulate practical recommendations for English teachers on the organization of educational material. The instructional design of the programme includes educational content, artificial intelligence applications, neuro and cognitive science which deals with brain structure and associated neural activity, including psychomotor behavior, recall of information, and decision-making processes. 
Table 2. Approaches in the design of instructional materials

\begin{tabular}{|c|c|c|c|}
\hline $\begin{array}{c}\text { Psycho-pedagogical } \\
\text { approach }\end{array}$ & Books and Programmes & Skills developed & Specific Techniques \\
\hline $\begin{array}{l}\text { Basic competency \& } \\
\text { anthropology }\end{array}$ & $\begin{array}{l}\text { Student's Book } \\
\text { "English for nautical en- } \\
\text { gineers" }\end{array}$ & $\begin{array}{l}\text { Analyzing; } \\
\text { Simplifying; } \\
\text { Generalizing; } \\
\text { Empathy; } \\
\text { Digitalization; } \\
\text { Cognition } \\
\end{array}$ & $\begin{array}{l}\text { Educating } \\
\text { learning habits; } \\
\text { memory exercises, creative think- } \\
\text { ing development exercises, etc }\end{array}$ \\
\hline $\begin{array}{l}\text { Professional \& } \\
\text { linguistic } \\
\text { competency }\end{array}$ & $\begin{array}{l}\text { Student's Book } \\
\text { "Technical English for } \\
\text { nautical engineers" }\end{array}$ & $\begin{array}{l}\text { Describing objects } \\
\text { and processes; } \\
\text { Discussing ad- } \\
\text { vantages } \\
\text { and shortcomings; } \\
\text { Analyzing }\end{array}$ & $\begin{array}{l}\text { Development of technical thinking, } \\
\text { pieces of training to transform tech- } \\
\text { nical thought into speech }\end{array}$ \\
\hline $\begin{array}{l}\text { Use of digital } \\
\text { technologies }\end{array}$ & $\begin{array}{l}4 \text { years Bachelor } \\
\text { Programme }\end{array}$ & $\begin{array}{l}\text { Search for infor- } \\
\text { mation; } \\
\text { Widening outlook; } \\
\text { Developing social } \\
\text { skills }\end{array}$ & $\begin{array}{l}\text { Q-codes with links to videos and } \\
\text { texts; } \\
\text { Simulators; } \\
\text { Teacher's Youtube channel; } \\
\text { Viber group; } \\
\text { Internet blog of ESP department }\end{array}$ \\
\hline $\begin{array}{l}\text { Language of science } \\
\text { and technologies }\end{array}$ & $\begin{array}{l}\text { Student's Book } \\
\text { "Business English" }\end{array}$ & $\begin{array}{l}\text { Problems solving; } \\
\text { Taking decisions; } \\
\text { Explaining, } \\
\text { Creative thinking } \\
\text { development }\end{array}$ & $\begin{array}{l}\text { Contemporary technical reading; } \\
\text { Making presentations }\end{array}$ \\
\hline $\begin{array}{l}\text { Learner-centered } \\
\text { training }\end{array}$ & $\begin{array}{l}4 \text { years Bachelor } \\
\text { Programme }\end{array}$ & $\begin{array}{l}\text { Intelligence } \\
\text { development }\end{array}$ & $\begin{array}{l}\text { Taking into account the individual } \\
\text { mental abilities of students, their } \\
\text { motivations }\end{array}$ \\
\hline
\end{tabular}

1. In our view, a learner-centered approach does not mean adjusting to the student's wishes but taking into account his or her cognitive abilities. We summarized when student's memory work more efficiently. So, in order to develop learning skills, all four textbooks have the same structure, similar to training exercises. This way, we do not waste time explaining the content of the tasks.

2. Using distance learning every student had the opportunity to participate actively in learning activities from different areas via Social networks such as Viber, WhatsApp, Telegram and other messengers making questions, taking part in possible experiments or simulation processes.

3. Digital education is the innovative use of digital tools and technologies during teaching and learning, the use of digital technologies gave the educators the opportunity to design engaging learning opportunities in the courses of English for ship engineers. The 4 years course took the form of blended learning.

4. Special requirements to the texts in Student's Book "Technical English for nautical engineers" to develop professional and linguistic competency are as follows: the abstracts are mostly taken from authentic manuals but their length approximately 300 words. Do not go into technical details, emphasize the function description. Use 2-3 communicative questions before the text. Learn new words to the text but don't give the translation of them, students should get a motoric habit to look for the word in smartphone very quickly, find its synonyms, antonyms and analyze word-building. 
Prepare 2 exercises for text, whose aim is not for comprehension, but to remember the information. The exercises may be as follows: simplify the abstract of the text, paraphrase the sentence, choose the right statement, and give answers to the questions (no more than 5 questions). 20 minutes of such work will allow the students to retell the text or at least to give the main information they got from the text.

5. Grammar is reviewed 3 years of study in the form of tests. Tests are included in the textbooks "English for nautical engineers" and "Technical English for nautical engineers". Tests are mostly based on the contract between different grammar structures. We afforded 10 minutes for grammar test every lesson, checked the results and every student made self-assessment and studied grammar after the lesson to catch up with the group-mates.

6. Writing is included but mostly in the indirect form. Textbooks are provided with the lines for writing the answers to the questions, simplifying, generalizing, etc.

7. Work without home assignments, at the same time students may decide themselves what they should learn at home to improve their English.

8. Some classical exercises in the study of English in the era of advanced technology have become completely ineffective. For example, we no longer expect a student to translate text or sentences on their own without Google translator. And this has become a new challenge for foreign language teachers. The textbooks that have been used for decades have lost their effectiveness. Therefore, the main difficulty for us was to find up-to-date materials for both electronic and English language training for ship engineers as a whole. In whole, the students get satisfaction using technologies. The learners' adherence to attend online courses is greatly affected by their self-motivation, their information technology (IT) skills related to the use of computers and the Internet, their perceptions and attitudes towards the Internet and their cultural and non-English background [10]. Key challenges affecting the wider use of e-learning platforms include lack of adequate support for practical/laboratory work, the need to reformat/transform existing pedagogical content for on-line use, the added demands of on-line interactivity on the part of instructors/providers of content and the accessing them from resource constraint environments [15].

9. Having an interview in a crewing company is vital for all seafarers. The lecturers of Maritime English encounter the task of how to prepare students to it. The main motivation for students to study English was to "overcome" an interview in English, both internally at The Practice and Employment Department, and external with a representative of the crewing company. These interviews are not a test of the level of English proficiency, but of the student's overall readiness to take the shipboard training. This motivation justified and did not create student resistance to the use of learning by creating stressful situations (unprepared presentations, answered face to face to the teacher and in front of the group, audience noise, jokes-comments).

We have been training the students on how to pass an interview in many ways using the ideas of other scientists. Our interest was attracted by a new technique using the life grid for the interview [18]. The authors describe four attributes of the life grid technique that make it a unique and effective interviewing tool for studies of undergraduate science education. 


\subsection{Assessment of the course efficiency}

We used three criteria for the efficiency estimation of experimental course of English for ship engineers: 1) the decisions of a representative of a crewing company to reject the applicant (the student applying for the position of Engine Cadet); 2) the results of international tests for Engine Cadets; 3 ) attendance dynamics. We had been comparing the results shown by the control and the experimental groups for 4 years (30 students of the control group and 30 students of the experimental group).

According to the first criterion, the course was estimated at the end of the second and third year of study - the time when the representatives of the crewing companies usually interview the students in our educational institution. First, the students were asked to tell about themselves, about their choice of profession and work experience. The next phase of the interview contained questions about the technical features of different technical units.

Table 3. Number of applicants rejections $\%$

\begin{tabular}{|c|c|c|c|}
\hline Year & Experimental group & Control group & Difference \\
\hline 2018 & 36 & 47 & 11 \\
\hline 2019 & 18 & 28 & 10 \\
\hline
\end{tabular}

As it is shown in table 3, both groups improved their knowledge, dynamics is the same but the number of rejections in the control group 10\% higher each year compared with the experimental group. The super-intendants noted that the interviewed students from the experimental group behaved more confidently than from the control group, answered the questions with correctly formed phrases. We compare the number of rejections due to poor foreign language competence because the acceptance to the Engine Cadet position depends on the factors, which are not connected with the level of English.

The next step of the assessment was testing. We used the internationally accepted test "Marlins", the test for Engine Cadets.

Table 4. "Marlins test" results taken on the second and third year of study (\%)

\begin{tabular}{|c|c|c|c|c|c|c|c|c|}
\hline \multirow{2}{*}{$\begin{array}{c}\text { Levels of } \\
\text { diagnosted } \\
\text { parameters }\end{array}$} & \multicolumn{2}{|c|}{ First Test } & \multicolumn{2}{|c|}{ Second Test } & \multicolumn{4}{|c|}{ Difference of indexes } \\
\hline & \begin{tabular}{|l|} 
Control \\
group
\end{tabular} & \begin{tabular}{|c|} 
Experimen \\
tal group
\end{tabular} & $\begin{array}{c}\text { Control } \\
\text { group }\end{array}$ & \begin{tabular}{|c|} 
Experimen \\
tal group
\end{tabular} & $\begin{array}{c}\text { Control } \\
\text { group }\end{array}$ & $p \leq$ & \begin{tabular}{|c|} 
Experimen \\
tal group
\end{tabular} & $p \leq$ \\
\hline High & 0 & 0 & 19,8 & 66 & $+19,8$ & \multirow{3}{*}{0,05} & +66 & \multirow[t]{3}{*}{0,001} \\
\hline Middle & 9,9 & 16,5 & 23,1 & 26,4 & $+13,2$ & & $+9,9$ & \\
\hline Low & 90,1 & 83,5 & 67 & 7,6 & $-23,1$ & & $-75,9$ & \\
\hline
\end{tabular}

The second criterion used was the attendance of English by students of researched groups. Low attendance is directly proportional to low grades. The correlation was noted between student attendance and student achievement in higher education classrooms [24]. Students of maritime institutions miss lectures due to various objective reasons like illness, family problems, shipboard training and subjective reasons like 
lack of motivation and self-control, lost interest, etc. We see the decrease of attendance in control group each academic year (see table 5).

Table 5. Attendance dynamics in the control group

\begin{tabular}{|l|l|l|l|l|l|l|l|l|}
\hline Years & $\begin{array}{l}\text { Indicator } \\
\text { (row } \\
\text { levels) }\end{array}$ & $\begin{array}{l}\text { Absolute } \\
\text { increase } \\
\text { (decrease) }\end{array}$ & $\begin{array}{l}\text { Clarity } \\
\text { indicator } \\
\%\end{array}$ & $\begin{array}{l}\text { Growth index } \\
\text { (decrease) \% }\end{array}$ & $\begin{array}{l}\text { Growth rate } \\
\text { (decrease) \% }\end{array}$ & $\begin{array}{l}\text { Value of } \\
\text { 1\% } \\
\text { increase }\end{array}$ & $\begin{array}{l}\text { Interval } \\
\text { enlarge- } \\
\text { ment } \\
\text { method }\end{array}$ & $\begin{array}{l}\text { Moving } \\
\text { average } \\
\text { method }\end{array}$ \\
\hline 2016 & 8 & no & 100.0 & no & no & no & & 7.6 \\
\hline 2017 & 4 & -4.0 & 50.0 & 50.0 & -50.0 & 0.1 & \multirow{2}{*}{6.0} & 4.7 \\
\hline 2018 & 2 & -2.0 & 25.0 & 50.0 & -50.0 & 0.0 & & 2.7 \\
\hline 2019 & 2 & 0.0 & 25.0 & 100.0 & 0.0 & NaN & 2.0 & 1.6 \\
\hline
\end{tabular}

We took measures to improve students' attendance: developed habits to learn; facilitated learning by using digital technologies, adopted material to cognitive abilities oft he students, facilitated self-study by using the anthropological approach, widened motivation using student-centered approach. The course is distinguished by the integrity of the presentation of material in textbooks, which allows to maintain interest in learning all 4 years of study. You can see in table 6 small decrease in attendance in the experimental group too. We compared attendance dynamics of control and experimental groups with unpaired $t$-test. $\mathrm{P}$ value and statistical significance: The two-tailed $P$ value equals 0.0162 . By conventional criteria, this difference is considered to be statistically significant. Confidence interval: The mean of control minus experimental group equals $-4.3 ; 95 \%$ confidence interval of the difference is from -7.3 to -1.3 .

Intermediate interval: $t=3.99 ; \mathrm{df}=4$; standard error of difference $=1.085$

Table 6. Attendance dynamics in the experimental group

\begin{tabular}{|c|c|c|c|c|c|c|c|c|}
\hline Years & $\begin{array}{c}\text { Indicator } \\
\text { (row } \\
\text { levels) }\end{array}$ & $\begin{array}{c}\text { Absolute } \\
\text { increase } \\
\text { (decrease) }\end{array}$ & $\begin{array}{c}\text { Clarity } \\
\text { Indicator } \\
\%\end{array}$ & $\begin{array}{c}\text { Growth } \\
\text { index } \\
\text { (decrease) } \\
\text { \% }\end{array}$ & $\begin{array}{c}\text { Growth } \\
\text { rate } \\
\text { (decrease) } \\
\text { \% }\end{array}$ & $\begin{array}{c}\text { Value of } \\
\mathbf{1 \%} \\
\text { increase }\end{array}$ & $\begin{array}{c}\text { Interval } \\
\text { enlargement } \\
\text { method }\end{array}$ & $\begin{array}{c}\text { Moving } \\
\text { average } \\
\text { method }\end{array}$ \\
\hline 2016 & 8 & no & 100.0 & no & no & no & & 7.6 \\
\hline 2017 & 7 & -1.0 & 87.5 & 87.5 & -12.5 & 0.1 & 7.5 & 7.7 \\
\hline 2018 & 8 & 1.0 & 100.0 & 114.3 & 14.3 & 0.1 & & 7.0 \\
\hline 2019 & 6 & -2.0 & 75.0 & 75.0 & -25.0 & 0.1 & 7.0 & 6.7 \\
\hline
\end{tabular}

The tasks of the research were fulfilled completely. We developed Engineering Pedagogy by adding an effective approach for teaching English for future engineers, described the content of a 4-year course of English for ship engineers (Bachelor degree) based on new demands of the society to the civil engineers. The results of a four -year experimental training prove the efficiency of students' books designed according to new approaches. We developed practical recommendations to the teachers of English for civil engineers on how to organize instructional material effectively. 


\section{Discussion}

Our studies are consecrated on the development of modern principles for creating educational materials for studying a foreign language by engineering students. We suggested approaches and insist on their effectiveness. However, questions may arise why we combined basic competencies with anthropology. Without such a union training materials would become universal in the international maritime industry. The scientists E. Boulougouris, P. Mizythras, L. Chrysinas [1] describe the projects which focus on the foundation of European maritime educational programmes and offer internationally accepted modules. The essence of the discussion is whether it is possible to create a similar international module of English language training for ship engineers? We believe that it is possible to create a list of topics and tests to assess the level of proficiency in professional language of ship engineers, but the learning technologies and cognitive abilities of students are anthropologically influenced (different models of perception of the world, different structure of languages, different physiology of the language apparatus, etc.) and this fact makes creating a universal course challenging.

There are additional discussions concerning future learning and digital education. There are many thoughts that digital education may replace face-to-face learning. With the rapid development of digital education, students have their own virtual reality, which deals with smartphones and Internet resources use. I. Ipek, R. Ziatdinov [8] emphasize that there are new technologies for the future, based on cybernetics and nanotechnology, and can provide aid programs, such as electronic paper and wearable technology, in instructional design. There are other cases, such as digital education as pedagogy online, where teachers can be replaced with computer-based tutors, and where universities will be moving towards the hosting of online courses, in the next decade [19].

We believe that the role of the virtual environment in the process of obtaining knowledge is exaggerated. Kinesthetic students prefer printed materials, where they can take notes, turn pages, mark important information. The students' surveys on how much this training programme and textbooks in particular corresponded to their expectations allowed us to identify the following disadvantages: limited amount of e-learning material, lack of readiness of teachers to interact with students via modern multimedia tools, complexity of the material is oriented to the average initial level of the student thus does not take into account individual approach. The shortcomings identified are not fundamental and will be corrected in subsequent editions of the textbooks.

\section{Conclusion and Future Work}

According to the purpose of our article, we have shared the experience of teaching English to ship engineers. We have formed the theoretical psychological and methodological foundations based on which a four-year Bachelor's English language curriculum was developed for the Faculty of Technical Systems Operation of Water Transport. Five principles (approaches) have become the basis for textbook and programme design: 1) development of basic competencies with anthropology approach; 2) 
development of professional and linguistic competencies; 3) use of digital technologies; 4) language of science and technologies as the way to innovations; 5) learner-centered with cognition abilities approach.

We estimated the effectiveness of the four-year experimental teaching of the English language according to the textbooks developed for the students - future ship engineers on the basis of five modern approaches to organizing educational material on three criteria. The students of the experimental group showed a $10 \%$ reduction in the number of refusals after the interview with a representative of the crewing company due to insufficient knowledge of the English language than in the control group, $66 \%$ higher the number of students who passed a professional English test with high scores, and also showed positive attendance of the English classes.

We formulated practical recommendations for English teachers on the organization of educational material. The recommendations include educational content and cognitive science which deals with brain structure and associated neural activity, including psychomotor behavior, work of memory, problem-solving and decision-making processes.

The prospect of further development of the results of experimental training may be a joint project of developing an international modular English course for ship engineers.

\section{Acknowledgment}

We are grateful to the representatives of crewing company "Columbia Shipmanagement Ukraine LTD for conducted interviews with the participants of experimental training.

\section{References}

[1] Boulougouris, E., Mizythras, P., Chrysinas, L. et al. (2019). Developing multidisciplinary blended learning courses for maritime education with cross-European collaboration. WMU J Marit Affairs 18, 319-340. https://doi.org/10.1007/s13437-019-00167-x

[2] Duschl, R.A. (2019). Learning progressions: framing and designing coherent sequences for STEM education. Disciplinary and Interdisciplinary Science Education Research https://doi. org/10.1186/s43031-019-0005-x

[3] European Commission Recommendation of the European Parliament and of the Council of 18 December 2006 on key competences for lifelong learning. In: Official Journal of the European Union, pp 10-18

[4] Galvis, Á.H. Supporting decision-making processes on blended learning in higher education: literature and good practices review. Int J Educ Technol High Educ 15, 25 (2018). https:// doi.org/10.1186/s41239-018-0106-1

[5] Hasse C. (2012) Anthropology of Learning and Cognition. In: Seel N.M. (eds) Encyclopedia of the Sciences of Learning. Springer, Boston, MA

[6] [6] Ifenthaler, D. (2012). Blended Learning. In: Seel N.M. (eds) Encyclopedia of the Sciences of Learning. Springer, Boston, MA

[7] IMO Model Course 3.17 Maritime English, published in 2000 by the International Maritime Organization, 4 Albert Embankment, London SE1 7SR2009 
[8] Ipek, I., Ziatdinov R. (2017) New Approaches and Trends in the Philosophy of Educational Technology for Learning and Teaching Environments. European Journal of Contemporary Education, 2017, 6(3). https://doi.org/ 10.13187/ejced.2017.3.381

[9] Jónasson, J. T. (2016). Educational change, inertia and potential futures. Eur J Futures Res (2016) 4: 7. https://doi.org/10.1007/s40309-016-0087-z

[10] Kebritchi M, Lipschuetz A, Santiague, L. (2017). Issues and challenges for teaching successful online courses in higher education. Journal of Educational Technology Systems 46(1): pp. 4-29. https://doi.org/10.1177/0047239516661713

[11] The Manila Amendments to the Seafarers' Training, Certification and Watchkeeping (STCW) Code, adopted at the Conference of Parties to the International Convention on Standards of Training, Certification and Watchkeeping for Seafarers, 1978, 3 August 2010. https://doi.org/10.1016/b978-0-08-097170-4.00007-6

[12] Martes, L. (2015). Revision of IMO Model Course 3.17 Maritime English. Focus on Maritime English to Auxiliary Personnel. The International Journal on Marine Navigation and Safety of Sea Transportation, Volume 9, Number 3, September 2015. https://doi.org/10. $12716 / 1001.09 .03 .02$

[13] Martin, D. (2018) Shaping the Digital Future in Education - Together. International Journal of Engineer Pedagogy (iJEP) Vol. 8, No. 2, 2018. https://doi.org/10.3991/ijep.v8i2.8228

[14] McLaughlin, H., McConville, J. (2002). The Economics of the Seafaring Labour Market. In C. Grammenos (Ed.), The Handbook of Maritime Economics and Business (1 ed., pp. 443468). London: Lloyds of London Press.

[15] Onime, C., Uhomoibhi, J. (2017) Augmenting E-learning Tools for STE Disciplines and Resource Constrained Environments. In: Auer M., Guralnick D., Uhomoibhi J. (eds) Interactive Collaborative Learning. ICL 2016. Advances in Intelligent Systems and Computing, vol 545. Springer, Cham. https://doi.org/10.1007/978-3-319-50340-0 26

[16] Prasad R. et al. (2011) Collaborative learning for professional development of shipboard engineers. International Journal of Engineering Science and Technology (IJEST) Vol. 3 No. 3 March 2011

[17] Progoulaki, M., Roe, M. Dealing with multicultural human resources in a socially responsible manner: a focus on the maritime industry. WMU J Marit Affairs 10, 7-23 (2011). https://doi.org/10.1007/s13437-011-0003-0

[18] Rowland et al. (2019). Using the life grid interview technique in STEM education research International Journal of STEM Education (2019) 6:32. https://doi.org/10.1186/s40594-019$\underline{0186-\mathrm{Z}}$

[19] Sharples, M. (2016). Digital education: Pedagogy online. Retrieved from http://www.nature.com/nature/journal/v540/n7633/full/540340a.html

[20] Schmidt, B. (2015). Students' Perception of Different Learning Options and Use of Authentic Research Papers in a First Year Engineering Course. International journal of Engineering Pedagogy, Volume 5, Issue 4, 2015. https://doi.org/10.3991/ijep.v5i4.4923

[21] Vorbach, S., Poandl, E., Korajman, I. (2019). Digital Entrepreneurship Education - The Role of MOOCs. International journal of Engineering Pedagogy, Vol.9, № 3, 2019. https:// doi.org/10.3991/ijep.v9i3.10149

[22] Wheeler, S. (2012). e-Learning and Digital Learning. In: Seel N.M. (eds) Encyclopedia of the Sciences of Learning. Springer, Boston, MA DOI: https://doi.org/10.1007/978-1-44191428-6_431

[23] Záhorec,J, Nagyová,A., Hašková A.(2019). “Teachers’ Attitudes to Incorporation Digital Means in Teaching Process in Relation to the Subjects they Teach". International journal of Engineering Pedagogy, Vol.9, № 4, 2019. https://doi.org/10.3991/ijep.v9i4.11064 
[24] Zaid N. Al-Shammari Kris Gritter (Reviewing Editor) (2016) Enhancing higher education student attendance through classroom management, Cogent Education, 3:1, https://doi.org/ $\underline{10.1080 / 2331186 x .2016 .1210488}$

\section{$7 \quad$ Authors}

Tyron O. is anAssociate Professor, PHD in Educational Psychology; a member of IMLA (International Maritime Lectures Association), a member of IATEFL (International Association of Teachers of English as a Foreign Language), the author of over 40 articles in psychology and psycholinguistics, the author of series of students' books for nautical engineers, the book of psychological games and techniques for navigators.

Korieshkova S. is an Associate Professor, PHD in Pedagogy, the Head of ESP department, a member of IMLA (International Maritime Lectures Association), a member of IATEFL (International Association of Teachers of English as a Foreign Language), the author of over 35 articles in comparative pedagogy and methods of teaching foreign languages, the author of series of students' books for navigators, has a patent on the dictionary for navigators.

Didenko M. is aSenior lecturer of Maritime English, the author of 10 articles in methods of teaching English, a member of IATEFL (International Association of Teachers of English as a Foreign Language), the co-author of students' books for navigators, has a patent on the dictionary for navigators.

Kaminska S.is a Senior lecturer of Maritime English, the author of 5 articles in methods of teaching English, a member of IATEFL (International Association of Teachers of English as a Foreign Language), a participant in the International Educational Project Tempus IV (Trans-European Mobility Programme for University Studies), the co-author of students' books for navigators.

All authors work at the State University of Infrastructure and Technologies, Kyiv, Ukraine.

Article submitted 2020-03-06. Resubmitted 2020-06-24. Final acceptance 2020-07-02. Final version published as submitted by the authors. 